\title{
Peran Pendidik dalam Pembelajaran Berbasis Gender pada Anak Usia Dini di Kober Tunas Bangsa
}

\author{
Uswatun Hasanah ${ }^{1}$, \\ ${ }^{1}$ Institut Agama Islam Negeri Metro Lampung
}

\begin{tabular}{ll}
\hline \hline \multicolumn{2}{l}{ Info Artikel : } \\
\hline Diterima & $:$ 18 September 2019 \\
Direvisi & $:$ 20 September 2019 \\
Dipublis & $:$ 06 Oktober 2019
\end{tabular}

Kata Kunci:

Peran Pendidik

Pembelajaran berbasis Gender

Anak Usia Dini

Keywords:

The Role of Educator

Gender-Based Learning

Early Childhood

\begin{abstract}
ABSTRAK
Peran Gender perlu dikenalkan oleh pendidik sejak dini dikarenakan sangat erat kaitannya dengan perkembangan dan pembentukan pola perilaku dan kepribadian anak di masa dewasa. Penelitian ini bertujuan untuk mengetahui peran pendidik dalam pembelajaran berbasis gender di Kober Tunas Bangsa. Metode Penelitian ini menggunakan pendekatan kualitatif deskriptif. Subjek penelitian adalah kepala sekolah, pendidik, dan peserta didik di Kober Tunas Bangsa. Hasil penelitian menunjukkan bahwa pelaksanaan pembelajaran berbasis gender dilaksanakan melalui keteladanan, pembiasaan, dan pendidik tidak bersikap diskriminatif pada permainan peserta didik ketika mereka bermain. Selain itu, tidak ada materi atau tema khusus yang membahas tentang gender di dalam RPPH, karena sesungguhnya semua nilai-nilai gender sudah terintegrasi dalam proses pembelajaran serta pendidik di Kober Tunas Bangsa menggunakan metode yang dalam proses pembelajaran berbasis gender dilakukan secara bervariasi.
\end{abstract}

\begin{abstract}
Since early, gender roles need to be introduced by educators. It relates to the development and formation of child behaviour and personality patterns in adulthood. This study aims to determine the role of educators in gender-based learning in Kober Tunas Bangsa. This research method uses a qualitative descriptive approach. Research subjects are the headmaster, educators, and learners in Kober Tunas Bangsa. The results showed that the implementation of gender-based learning was conducted through transparency, habituation and educators are not discriminatory about the learners games when they play. In addition, there is no special material or theme that talks about gender in the RPPH. The fact that all gender values are already integrated into the learning process and the educators at the Kober Tunas Bangsa use varied methods in the gender-based learning process.
\end{abstract}

\section{Koresponden:}

Uswatun Hasanah,

Email: u.hasanah19@rocketmail.com/uswatun.hasanah@metrouniv.ac.id

\section{Pendahuluan}

Anak memiliki kemampuan seluas samudra:kemampuan kognitif yang menghasilkan daya pikir positif, kemampuan psikomotorik yang menghasilkan karya bermanfaat dan penampilan yang dahsyat, serta kemampuan afektif yang menghasilkan nilai dan karakter yang manusiawi sesuai fitrahnya (Chatib, 2012). Pada rentang usia lahir sampai 6 tahun anak mengalami masa keemasan (the golden years) yang merupakan masa dimana anak mulai peka/sensitif untuk menerima berbagai rangsangan. Masa peka adalah masa terjadinya kematangan fungsi fisik dan psikis, masa peka anak masing-masing berbeda, seiring dengan laju pertumbuhan dan perkembangan anak secara individual. Masa ini juga merupakan masa peletak dasar pertama untuk mengembangkan kemampuan kognitif, sosio emosional, gerak-motorik, bahasa pada anak usia dini. Usia dini merupakan masa perkembangan yang sangat menentukan masa depan bangsa (Nurani Sujiono, 2013).

Dalam Undang-undang Sistem Pendidikan Nasional No.20 Tahun 2003 pada pasal 28 mejelaskan bahwa (1) Pendidikan Anak usia dini diselenggarakan sebelum jenjang pendidikan dasar; (2) Pendidikan Anak usia dini pada dapat diselenggarakan melalui jalur pendidikan formal, nonformal, dan atau informal; (3) Pendidikan Anak usia dini pada jalur pendidikan formal berbentuk taman kanak-kanak (TK), 
Raudhatul Athfal (RA), atau bentuk lain yang sederajat; (4) Pendidikan Anak usia dini pada jalur pendidikan non formal berbentuk Kelompok Bermain (KB), Taman Penitipan Anak (TPA), atau bentuk lain yang sederajat; (5) Pendidikan anak usia dini pada jalur pendidikan informal berbentuk pendidikan keluarga atau pendidikan yang diselenggarakan oleh lingkungan (D. P. Nasional, 2003).

Adapun peran gender diantaranya adalah perilaku yang dipelajari di dalam suatu masyarakat/komunitas yang dikondisikan bahwa kegiatan, tugastugas atau tanggung jawab patut diterima baik oleh lakilaki maupun perempuan. Peran gender dapat berubah, dan dipengaruhi oleh umur, kelas, ras, etnik, agama dan lingkungan geografi, ekonomi dan politik. Banyak hal yang mempengaruhi perkembangan gender anak. Faktor tersebut adalah faktor hormon dan keturunan, pengaruh sosial yang terdiri atas pola asuh, psikoanalisisnya, teman sebaya, sekolah dan pendidik, media elektronik. Selain itu juga ada faktor kognitif anak yang dapat mempengaruhi daya pikirnya tentang peran gender. Ada perhatian khusus bahwa sekolah dan pendidik memiliki bias terhadap anak laki-laki dan perempuan. Beberapa bukti menunjukkan bahwa di kelas terjadi biasa gender terutama terhadap laki-laki, salah satunya anak laki-laki sering dianggap nakal. Kepatuhan, mengikuti aturan, kerapian dan teratur biasanya sangat dihargai dan berusaha ditegakkan di dalam kelas, perilaku tersebut biasanya lebih mengkarakteristikkan anak perempuan daripada laki-laki. Pendidikan yang bias gender dapat melabel anak laki-laki sebagai anak yang berkerja di publik, bersifat kuat, pemberani, nakal, dan sifat-sifat maskulin lainya, sedangkan perempuan dianggap cocok bekerja dibagian domestik, bersifat lemah, penakut, mematuhi aturan dan sifat-sifat feminin lainnya (Indarni, 2012).

Dengan demikian, maka peneliti perlu mengenalkan peran gender sejak dini dikarenakan sangat erat kaitannya dengan perkembangan dan pembentukan pola perilaku dan kepribadian anak di masa dewasa. Oleh karena itu segala jenis informasi yang benar dan berkaitan erat dengan peran gender harus ditanamkan secara tepat agar dapat tersimpan di memori anak dalam jangka panjang.

\section{Metode}

Jenis penelitian ini adalah penelitian lapangan (field research) sebuah penelitian dengan prosedur penelitian yang menggali data dari lapangan untuk kemudian dicermati dan disimpulkan. Adapun sifat penelitian ini bersifat kualitatif atau Naturalistik. Penelitian penggunaan kualitatif ini juga bertujuan supaya data-data yang diperoleh mendalam sesuai dengan makna dan fakta di lapangan. Pada dasarnya penelitian kualitatif berusaha untuk mendeskripsikan permasalahan secara komprehensif, holistic, integratif dan mendalam melalui kegiatan mengamati orang dalam lingkungannya dan berinteraksi dengan mereka mengenai dunia sekitar. Dengan kata lain, penelitian ini di sebut penelitian kualitatif karena merupakan penelitian yang tidak mengadakan perhitungan (Nasution, 1988) .

Penelitian ini menggunakan metode deskriptif karena melalui metode ini peneliti ingin memaparkan kondisi pendidik dalam pembelajaran berbasis gender yang berlangsung di Kober Tunas Bangsa secara menyeluruh, luas, dan mendalam, baik kegiatan pendidik dalam merencanakan pembelajaran, perilaku belajar anak, metode dan media yang digunakan pendidik. Pendekatan penelitian yang digunakan dalam penelitian mengenai pengenalan peran gender dalam pembelajaran pada peserta didik di Kober Tunas Bangsa ini adalah pendekatan penelitian kualitatif, dengan menggunakan metode studi deskriptif, hal ini dikarenakan pemaparan hasil penelitian yang dipilih peneliti tidak menggunakan statistik dan angkaangka.

Teknik pengumpul data dalam penelitian ini adalah: (1) Teknik observasi langsung yang dilakukan terhadap obyek di tempat berlangsungnya peristiwa, sehingga observer ada di tempat yang sama dengan obyek yang diamati. Peneliti menggunakan bentuk observasi partisipan dengan alat pengumpul data berupa panduan observasi dan catatan lapangan. Teknik ini digunak untuk mengobservasi kemampuan pendidik dalam merencanakan pembelajaran, observasi kemampuan pendidik dalam melaksanakan pembelajaran, dan perilaku belajar anak dalam mengenal peran gender. (2) Teknik wawancara tidak terstruktur adalah cara pengambilan data penelitian dengan cara peneliti menentukan fokus masalah saja dan tidak memberikan alternatif jawaban yang harus dipilih oleh informan (3) Teknik dokumentasi adalah cara mengumpulkan data melalui peninggalan tertulis, terutama berupa arsip-arsip dan termasuk juga buku-buku tentang pendapat, teori, dalil/hukumhukum dan lain-lain yang berhubungan dengan masalah penyelidikan. Adapun data-data yang dikumpulkan dalam penelitian ini yaitu berupa arsip-arsip seperti Rencana Pelaksanaan Pembelajaran Harian (RPPH), profil sekolah, jumlah peserta didik, jumlah pendidik, foto-foto pada saat pembelajaran, seluruh data hasil dokumentasi dapat menunjang proses penelitian. Proses analisis data selama di lapangan menggunakan model interaktif dari Miles dan 
Huberman. Analisis data terdiri dari tiga alur kegiatan yang dapat terjadi secara bersamaan yaitu: reduksi data, penyajian data, penarikan kesimpulan/verifikasi Miles dan Huberman.

Analisis data penelitian kualitatif dilakukan sejak awal penelitian hingga akhir dengan harapan adanya konsistensi dalam analisis data. Analisis data yang digunakan dalam penelitian ini menggunakan analisis deskriptif dengan model Analisis Interaktif dari Miles dan Huberman (Moleong, 2007). Dalam proses kualitatif Miles dan Huberman mengemukakan bahwa: "we define analysis as consisting of three concurant flow of activity, data reduction, data display and conclution drawing/verification. Ketiga proses ini terjadi terus-menerus selama pelaksanaan penelitian, baik pada periode pengumpulan data maupun setelah data terkumpul seluruhnya.

\section{Hasil dan Pembahasan}

Anak merupakan amanah Allah kepada kedua orangtuanya, hatinya masih suci bagaikan mutiara yang indah, bersih dan kosong dari segala ukiran gambar. Dia siap menerima segala ukiran dan cenderung kepada setiap apa yang diarahkan kepadanya. Anak yang mendapatkan pembinaan yang tepat pada usia dini akan dapat meningkatkan kesehatan serta kesejahteraan fisik dan mental, yang berdampak pada peningkatan prestasi belajar anak, etos kerja anak, dan produktivitas sehingga mampu mandiri dan mengoptimalkan potensi dirinya (El Khuluqo, 2015).

Anak usia dini bertumbuh dan berkembang menyeluruh secara alami. Jika pertumbuhan dan perkembangan tersebut dirangsang maka akan mencapai. Aspek perkembangan motorik merupakan salah satu aspek perkembangan yang dapat mengintegrasikan perkembangan aspek yang lain. Menurut UU Nomor 20 Tahun 2003 Bab I Pasal 1 Ayat 14 tentang pendidikan bahwa pendidikan anak usia dini adalah suatu upaya pembinaan yang ditujukan kepada anak sejak lahir sampai dengan usia enam tahun yang dilakukan melalui pemberian rangsangan pendidikan untuk membantu pertumbuhan dan perkembangan jasmani dan rohani agar anak memiliki kesiapan dalam memasuki pendidikan lebih lanjut (K. P. Nasional, 2003). Pendidikan anak usia dini (early childhood education/ PAUD) sangat penting dilaksanakan sebagai dasar bagi pembentukan kepribadian manusia secara utuh, yaitu pembentukan karakter, budi pekerti luhur, cerdas, ceria, terampil, dan bertakwa, kepada Tuhan yang Maha Esa

Masa usia dini merupakan masa paling penting untuk sepanjang kehidupannya, sebab masa usia dini adalah masa pembentukan pondasi dan dasar kepribadian yang akan menentukan pengalaman selanjutnya. Demikian pentingnya usia dini, maka kebutuhan anak usia dini mutlak dipenuhi. Perubahan dalam satu dimensi akan mempengaruhi dimensi lainnya. Banyak para ahli yang menilai bahwa periode 5 tahun sejak kelahiran akan menentukan perkembangan selanjutnya (Wiyani, 2016).

Adapun aspek-aspek perkembangan anak usia dini, diantaranya (Nurani Sujiono, 2013):

a. Kesadaran personal Permainan yang kreatif memungkinkan perkembangan kesadaran personal. Bermain mendukung anak untuk tumbuh secara mandiri dan memiliki kontrol atas lingkungannya. Melalui bermain, anak dapat menemukan hal yang baru, bereksplorasi, meniru, dan mempraktikkan kehidupan sehari-hari sebagai sebuah langkah dalam membangun keterampilan menolong dirinya sendiri, keterampilan ini membuat anak merasa kompeten.

b. Pengembangan Emosi Melalui bermain, anak dapat belajar menerima, berekspresi dan mengatasi masalah dengan cara yang positif. Bermain juga memberikan kesempatan pada anak untuk mengenal diri mereka sendiri dan untuk mengembangkan pola perilaku yang memuaskan dalam hidup.

c. Membangun sosialisasi Bermain memberikan jalan bagi perkembangan sosial anak ketika berbagi dengan anak lain. Bermain adalah sarana yang paling utama bagi pengembangan kemampuan bersosialisasi dan memperluas empati terhadap orang lain serta mengurangi sikap egosentrisme. Bermain dapat menumbuhkan dan meningkatkan rasa sosialisasi anak. Melalui bermain anak dapat belajar perilaku prososial seperti: menunggu giliran, kerja sama, saling membantu dan berbagi.

d. Pengembangan Komunikasi. Bermain merupakan alat yang paling kuat untuk membelajarkan kemampuan berbahasa anak. Melalui komunikasi inilah anak dapat memperluas kosa kata dan mengembangkan daya penerimaan serta pengekpresian kemampuan berbahasa mereka melalui interaksi dengan anak-anak lain dan orang dewasa pada situasi bermain spontan.

e. Pengembangan kognitif. Bermain dapat memenuhi kebutuhan anak untuk secara aktif terlibat dengan lingkungan, untuk bermain dan bekerja dalam menghasilkan suatu karya, serta untuk 
memenuhi tugas-tugas perkembangan kognitif lainnya. Selama bermain, anak menerima pengalaman baru, memanipulasi bahan dan alat, berinteraksi dengan orang lain dan mulai merasakan dunia mereka. Bermain menyediakan kerangka kerja pada anak untuk mengembangkan pemahaman tentang diri mereka sendiri, orang lain dan lingkungan.

f. Pengembangan kemampuan motorik. Bermain memberikan kesempatan yang luas untuk bergerak pada anak, pengalaman belajar untuk menemukan, , aktivitas sensori motor, yang meliputi penggunaan otot-otot besar dan kecil memungkinkan anak untuk memenuhi perkembangan perseptual motorik.

Proses pembelajaran pendidikan anak usia dini selalu menggunakan kacamata gender sebagai alat untuk mereview bahan ajar yang digunakan, apakah bahan ajar tersebut mengandung bias gender atau tidak, hal ini dilakukan untuk menghindari adanya pengaruh diskriminatif terhadap pola perilaku peserta didik.

Istilah pembelajaran berasal dari kata "belajar" yaitu aktivitas untuk memperoleh pengetahuan, meningkatkan keterampilan, memperbaiki perilaku, sikap dan mengukuhkan kepribadian. Maksud dari pengertian ini lebih menunjukkan pada perubahan individu, baik ilmu pengetahuan maupun sikap dan kepribadian. Selain itu, pembelajaran merupakan kegiatan yang mengupayakan pembelajaran siswa secara integrasi dengan memperhitungkan faktor lingkungan belajar dan karakteristik anak (Uno, 2007).

Dalam pembelajaran bukan hanya sekedar "transfer of knowledge" namun merupakan "a change of behavior" yaitu proses perubahan perilaku pada diri anak yang mengalami kegiatan belajar dari tidak tahu menjadi tahu, dari tidak bisa menjadi bias. Secara garis besar dalam kitab Ta'lim Muta'alim dijelaskan tugas seorang murid sehingga pengetahuan yang diperoleh dapat bermanfaat yaitu:"elingo dak kasil ilmu anging nem perkara, bakal tak ceritaake kumpule kanti pertelo. Rupane limpet, loba, sobar, ana sangune lan piwulange pendidik lan suwe mangsane" Sebagai seorang murid sebaiknya dalam mencari ilmu adalah limpet (cerdas), artinya mempunyai kemampuan untuk menangkap ilmu. Pada hakikatnya anak usia mempunyai kecerdasaran yang luar biasa karena rasa keingintahuan yang kuat, tergantung lingkungan untuk dapat mengembangkan kecerdasannya. Kedua loba (semangat), artinya sungguh-sungguh dengan bukti ketekunan. Anak usia dini yang masih bersih bagaikan kertas putih, mempunyai semangat untuk menghiasi kertas tersebut supaya ada hiasan. Semangat anak dapat luntur karena lingkungan yang kurang mendukung perkembangannya. Ketiga, sobar (sabar), artinya tabah meghadapi cobaan dan ujian dalam mencari ilmu. Sifat sabar yang dimiliki anak seperti halnya penerimaan diri dalam menerima semua yang diajarkan, walaupun yang diberikan kepadanya belum tentu baik, hal tersebut dikarenakan masih fitrahnya anak usia dini. Oleh karena itu sebagai pendidik diharapkan memberikan sesuatu yang bermanfaat bagi anak khususnya untuk mempersiapkan terjun ke masyarakat. Keempat, ana sangune (biaya), artinya orang mencari ilmu perlu biaya seperti manusia hidup yang memerlukannya. Biaya bukan hanya dinilai sebagai materi saja namun juga kesiapan diri. Kelima, piwulange pendidik (petunjuk pendidik), artinya mencari ilmu sesuai dengan petunjuk pendidik tidak boleh belajar sendiri (mengikuti bimbingan atau arahan pendidik). Poin ini menjadi penentu dalam menghiasi diri anak, menumbuhkembangkan kemampuan anak, tanpa pendidik maka tiada media transformasi ilmu. Keenam, suwe mangsane (jangka waktu), artinya butuh proses sebagaimana konsep menuntut ilmu sepanjang hayat. Untuk mengembangkan kemampuan anak bukan saja berdasarkan keturunan dari orang tua, namun untuk membutuhkan proses belajar sehingga tercapai tujuan untuk mempersiapkan dirinya dari aspek spiritual sampai sosial (Akbar, 2016).

Gender merupakan perbedaan perilaku antara laki-laki dan perempuan yang dikonstruksi secara sosial, yakni perbedaan yang diciptakan oleh manusia (bukan kodrat) melalui proses sosial dan kultural yang panjang. Selain itu, gender dapat diartikan juga sebagai konstruksi sosial, walaupun thorne merasa tidak puas dengan kerangka kerja sosialisasi gender (gender sosialization) dan 'pengembangan gender (gender development),karena konsep sosialisasi kebanyakan hanya satu arah. Pihak yang lebih berkuasa menyosialiasi pihak yang lebih lemah (Fakih, 1996).

Gender berasal dari bahasa Inggris, yang punya makna “jenis kelamin”. Sementara itu istilah jenis kelamin biasanya mengacu pada ciri organ biologis, seperti payudara, rahim, vagina, dan ovum untuk perempuan; dan memiliki penis dan sperma untuk laki-laki. Dengan demikian, arti gender yang semacam itu menjadi sama dengan sex (jenis kelamin), yang memfokuskan pada perbedaan aspek biologis dari seorang manusia, yaitu laki-laki dan perempuan. Dalam pengertian lain sebagaimana diungkap bahwa gender adalah interpretasi sosial dari seks, yaitu bagaimana jenis kelamin yang "kodrat" itu diterjemahkan menjadi peran sosial tertentu. Dalam Women's Studies Encyclopedia dijelaskan, bahwa gender adalah 
suatu konsep kultural yang berupaya membuat pembedaan (discrimination) dalam hal peran, perilaku, mentalitas, dan karakteristik emosional antara laki-laki dan perempuan yang berkembang di masyarakat. Selain itu, Gender merupakan seperangkat peran yang menunjukkan kepada orang lain bahwa seseorang itu feminin atau maskulin. Perangkat perilaku khusus ini yang mencakup penampilan, pakaian, sikap, kepribadian, bekerja di dalam dan di luar rumah tangga, tanggung jawab keluarga dan sebagainya - secara bersama-sama memoles "peran gender" anggota masyarakat. Di samping itu dalam The New Encyclopaedia Britannica diungkapkan bahwa identitas gender tidak ditentukan sejak anak lahir, tetapi merupakan kontribusi dari faktor-faktor fisiologis dan sosial, yang dibentuk dan disosialisasikan oleh masyarakat sampai anak mencapai kematangan (Shobahiya, 2012).

Dengan demikian, pendidikan berbasis gender jangan diterjemahkan sebagai upaya perempuan melawan laki-laki. Bukan demikian. Namun, bagaimana perempuan dapat mendapatkan kesetaraan nonkodrati. Yang dalam jangka panjang dapat meningkatkan perlindungan, pelayanan dan kesejahteraan kaum perempuan. Dimana Secara hukum, perempuan dan laki-laki memiliki hak, kesempatan, dan kewajiban yang sama untuk mendapatkan pendidikan.

Prestasi perempuan dalam dunia pendidikan masih dipandang rendah dibandingkan dengan kaum laki-laki. Hal itu menjadikan kaum perempuan belum memiliki ruang dalam menyalurkan aspirasiaspirasinya karena keterbatasan akses yang diirikan oleh masyarakat yang melegitimasi perbedaan peran dan kedudukan antara laki-laki dan perempuan. Apalagi dalam sebagian masyarakat kita berasumsi bahwa secara alamiah laki-laki diciptakan dengan kelebihan-kelebihan yang tidak didapat pada kaum perempuan. Anggapan semacam ini disebabkan oleh faktor-faktor kultural masyarakat paternalistik yang cenderung memposisikan perempuan sebagai second gender; masyarakat kelas dua. Secara psikologis, tidak ada satu pun teori yang menyebutkan bahwa laki-laki lebih cerdas dibandingkan kaum perempuan. Tidak ada satu data ilmiah pun yang menyatakan bahwa perempuan terlahir lebih bodoh dibandingkan kaum lelaki. Hasil tes intelegensi menunjukkan bahwa perempuan mendapatkan skor yang relatif sama dengan para lelaki (Zaduqisti, 2009).

Namun kenyataanya masih terdapat ketidaksetaraan gender yang cukup besar dalam bidang pendidikan di Indonesia. Ketidaksetaraan ini ditemukan tidak hanya melalui indikator yang dengan mudah diperoleh dari data sensus penduduk, seperti kemampuan membaca, penerimaan siswa baru, prestasi dan tingkat pendidikan yang dicapai, tetapi juga di beberapa aspek lain di bidang pendidikan yang menjadikan kesetaraan sebagai aspek yang cukup penting. Sebagai contoh dalam proses pendidikan masih ada perlakuan yang tidak adil (unfair treatment) yang merugikan anak perempuan misalnya, kegiatan pembelajaran dan proses interaksi dalam kelas seringkali bersifat merugikan murid perempuan. Secara tidak sadar, pendidik cenderung menaruh harapan dan perhatian yang lebih besar kepada murid laki-laki dibanding murid perempuan. Para pendidik kadangkala cenderung berpikir ke arah "selffulfilling prophecy" terhadap peserta didik yang perempuan karena menganggap perempuan tidak perlu memperoleh pendidikan yang tinggi. Kadang pendidik juga membedakan peran untuk anak laki-laki dan anak perempuan (Giraldo, 2008).

Dengan demikian citra, peran dan status sebagai perempuan, telah diciptakan oleh budaya. Citra bagi seorang perempuan seperti yang diidealkan oleh budaya, antara lain, lemah lembut, penurut, tidak membantah, tidak boleh "melebihi" laki-laki. Peran yang diidealkan seperti pengelola rumah tangga, sebagai pendukung karir suami, istri yang penurut dan ibu yang mrantasi. Citra yang dibuat untuk laki-laki antara lain, "serba tahu", sebagai panutan harus "lebih" dari perempuan, rasional, agresif. Peran laki-laki yang ideal adalah sebagai pencari nafkah keluarga, pelindung, "mengayomi", sedangkan status idealnya adalah kepala keluarga. Perempuan masih dianggap the second class yang sering disebut sebagai "warga kelas dua" yang keberadaannya tidak begitu diperhitungkan. Implikasi dari konsep dan common sense tentang pemosisian yang tidak seimbang telah menjadi kekuatan di dalam pemisahan sektor kehidupan ke dalam sektor "domestik" dan sektor "publik", di mana perempuan dianggap orang yang berkiprah dalam sektor domestik sementara laki-laki ditempatkan dalam sektor publik. Ideologi semacam ini telah disyahkan oleh berbagai pranata dan lembaga sosial, yang ini kemudian menjadi fakta sosial tentang status dan peran yang dimainkan oleh perempuan (Hermawati, 2007).

Pada dasarnya manusia yang dilahirkan di bumi itu memiliki kedudukan yang sama dan setara. Namun, kondisi sosial budaya pada masyarakat menjadikan laki-laki cenderung terlihat lebih superior dibandingkan dengan perempuan. Adanya keinginan menyetarakan peran antara laki-laki dan perempuan kemudian memunculkan gerakan feminisme yang sampai sekarang dipandang masih mampu menyuarakan perempuan (Umami, 2019). 
Anak laki-laki diberikan media bermain peran dengan peran yang maskulin misalnya, menjadi polisi dengan sosok yang tegas, gagah dan berani, sedangkan anak perempuan biasanya diminta memerankan sosok yang feminin, lemah lembut dan baik hati. Hal tersebut menunjukkan bahwa pendidikan anak usia dini masih kurang mendapatkan perhatian. Ditambah lagi budaya patriarki yang sudah mengakar kuat di masyarakat, semakin menguatkan pendidikan yang tidak adil dan setara untuk anak usia dini.

Anak-anak prasekolah menghabiskan hampir tiga kali lebih banyak waktu bermain bersama teman sesama jenis dari pada bersama pasangan seks lainnya. rasio ini meningkat menjadi 11 kali pada usia enam tahun. Kualitas bermain antara anak laki-laki dan perempuan telah terbukti menjadi berbeda. Anak laki-laki cenderung bermain kasar dan melibatkan keaktifan dan kekuatan melalui kontak fisik, seperti bertempur dan mengejek. Anak perempuan lebih cenderung bermain berpasangan. Kesetaraan gender meliputi penghapusan diskriminasi dan ketidakadilan struktural baik terhadap laki-laki maupun perempuan. Keadilan gender adalah suatu proses dan perlakukan adil yang tidak ada pembakuan, beban ganda, subordinasi, marginalisasi, dan kekerasan terhadap perempuan maupun laki-laki.Terwujudnya kesetaraan gender ditandai dengan tidak adanya diskriminasi dan adanya kesamaan dalam kesempatan berpartisipasi. Anak perempuan dan anak laki-laki mendapat perhatian dan rasa hormat yang sama. Dalam hal ini dan lainnya cara, mereka belajar untuk menghargai diri sendiri dan orang lain sama (Akbar, 2016).

Internalisasi nilai yang dilakukan sejak usia dini akan mengakar sampai hayat. Dalam konsep Islam tidak ditemukan adanya nilai-nilai dan pesan-pesan diskriminatif, baik terhadap perempuan ataupun terhadap laki-laki. Ayat-ayat yang mengungkap tentang relasi laki-laki dan perempuan menunjukkan adanya pesan kesetaraan antara laki-laki dan perempuan. Dengan demikian, nilai-nilai kesetaraan tersebut juga perlu dikembangkan pada anak-anak usia dini, baik dalam lembaga keluarga maupun lembaga pendidikan pra-sekolah. Dalam pembelajaran usia dini juga perlu dikembangkan pembelajaran yang berorientasi pada keseimbangan gender, dengan menghindarkan pembelajaran dari nilai-nilai yang bias gender, baik pada bidang pengembangan pembentukan perilaku maupun pada bidang pengembangan kemampuan dasar (Shobahiya, 2012).

Pada dasarnya setiap orang tua menginginkan anaknya tumbuh dan berkembang sesuai apa yang diharapkan. Jika seorang anak laki-laki, maka biasanya orang tua menginginkan anak laki-lakinya yang gagah dan perkasa, sehingga ketika anak laki-laki tersebut ingin bermain permainan seperti masakmasakan, main boneka, main lompat tali dan sebagainya orang tuanya akan marah dengan alasan karena permainan-permainan tersebut adalah permainan yang diperuntukkan bagi anak perempuan. Begitupun sebaliknya, anak perempuan dilarang bermain sepak bola, maen perang-perangan, memanjat pohon dan sebagainya, dengan alasan karena permainan-permainan tersebut dapat mengubah citra anak perempuan yang lemah lembut. Hal ini merupakan suatu kesalahan pola asuh yang dapat menyebabkan terjadinya kesalahpahaman pada diri anak. Padahal segala jenis permainan itu dapat membantu menumbuhkan dan mengembangkan berbagai potensi kecerdasan yang ada dalam diri setiap anak (Listyaningrum, Fahrurrozi, \& Meilani, 2018).

Berdasarkan hasil wawancara dengan pendidik di Kober Tunas Bangsa Kota Metro, dapat disimpulkan bahwa perencanaan pembelajaran di Kober Tunas Bangsa sudah sensitif gender. Hal ini dapat dilihat dari awal penentuan tema pembelajaran yang dilakukan melalui RPPH, pendidik di Kober Tunas Bangsa Kota Metro mampu melibatkan semua peserta didik untuk turut aktif berpartisipasi dalam kegiatan pembelajaran, pendidik juga memberikan keteladanan berupa berpakaian rapih, dan tidak mendiskriminasi peserta didik, semua peserta didik mempunyai hak untuk mengungkapkan pendapatnya tanpa membedakan apakah dia anak laki-laki, anak perempuan atau anak berkebutuhan khusus lainya. Selain itu dalam perencanaan pembelajaran tidak ada materi atau tema khusus di dalam RPPH yang membahas tentang gender, karena semua nilai-nilai gender sudah terintegrasi dalam proses pembelajaran.

Pendidik di Kober Tunas Bangsa Kota Metro menggunakan metode yang dalam proses pembelajaran berbasis gender dilakukan secara bervariasi, dan dilakukan dengan proses yang fleksibel,diantaranya yaitu: seperti metode demonstrasi, ceramah, drama, bermain peran, area, proyek, dan melalui pembiasaan, serta keteladanan, dengan menanamkan kepada peserta didik bahwa mereka memiliki kesempatan yang sama, dan hak sama. Adapun metode yang digunakan disesuaikan dengan karakteristik anak dan prinsip belajar anak usia dini yaitu metode yang memungkinkan bagi anak untuk banyak bergerak dan bereksplorasi, menentukan dan menemukan sendiri. Pendidik berperan sebagai fasilitator bagi peserta didik, yaitu berperan untuk mendorong dan mengembangkan informasi yang ingin peserta didik ketahui. Dalam proses pembelajaran berbasis gender, yang lebih ditekankan adalah pendidik 
memberi kesempatan yang sama kepada anak laki-laki dan perempuan baik dalam berpendapat maupun dalam bermain. Baik permainan di luar kelas maupun di dalam kelas.

\section{Referensi}

Akbar, E. (2016). Pembelajaran Gender pada Anak Usia Dini Melaui Pendekatan Sentra. Yinyang: Jurnal Studi Islam Gender Dan Anak, 11, 8.

Chatib, M. (2012). Orangtuanya Manusia: Melejitkan Potensi dan Kecerdasan dengan Menghargai Fitrah Setiap Anak. Kaifa.

El Khuluqo, I. (2015). Manajemen PAUD (Pendidikan Anak Usia Dini) Pendidikan Taman Kehidupan Anak. Yogyakarta: Pustaka pelajar.

Fakih, M. (1996). Analisis Gender dan Transformasi Sosial. Yogyakarta: Insist Press.

Giraldo, E. (2008). Uncovering gender relations and interactions promoted by early childhood curricula. Southern Illinois University at Carbondale.

Hermawati, T. (2007). Budaya Jawa dan Kesetaraan Gender. Jurnal Komunikasi Massa, 1(1), 18-24.

Indarni, N. (2012). Efektivitas Cerita Bergambar terhadap Pemahaman Peran Gender pada Anak di Taman Kanak-Kanak. Indonesian Journal of Early Childhood Education Studies, 1(1), 6.

Listyaningrum, E. M., Fahrurrozi, F., \& Meilani, R. S. M. (2018). Peningkatan Pengetahuan Gender Anak Usia 5-6 Tahun Melalui "Project Method." Prosiding Seminar Dan Diskusi Pendidikan Dasar, 106.

Moleong, L. J. (2007). Metodologi Penelitian Kualitatif Edisi Revisi. Bandung: PT Remaja Rosdakarya (Vol. 103).

Nasional, D. P. (2003). Sistem Pendidikan Nasional. Jakarta (ID): Depdiknas.

Nasional, K. P. (2003). Peraturan Kementerian Republik Indonesia. Undang-Undang Republik Indonesia Nomor 20 Tentang Sistem Pendidikan Nasional, p. Bab 1 Pasal 1.

Nasution, S. (1988). Metode Penelitian Naturalistik Kualitatif. Tarsito.

Nurani Sujiono, Y. (2013). Konsep Dasar PAUD. Jakarta: Indeks.

Shobahiya, M. (2012). Pembelajaran Berperspektif Gender dalam Islam untuk Anak Usia Dini. Suhuf, 24(1), 39.

Umami, R. H. (2019). Bias Gender dalam Sastra Anak: Studi pada Buku Kecil-kecil Punya Karya. Martabat, 2(1), 135-154.

Uno, H. B. (2007). Model Pembelajaran Menciptakan Proses Belajar Mengajar yang Kreatif dan Efektif. Jakarta: Bumi Aksara.

Wiyani, N. A. (2016). Konsep Dasar PAUD. Yogyakarta: Gaya Media.

Zaduqisti, E. (2009). Stereotype Peran Gender bagi Pendidikan Anak. Jurnal Muwazah Vol, 1, 73-82. 